\title{
THROUGH THE ADMISSIBILITY OF EVIDENCE MAZE: AN ATTEMPT AT A PURPOSIVE STRUCTURING
}

\author{
DONALD G. CASSWELL*
}

The purposes served by admissibility rules are crucial to an understanding and evaluation of them. They are similarly central to any attempt to structure those rules. In this article the author submits that courts are moving towards a purposive structuring of admissibility of evidence. An important aspect of this movement appears to be increased reliance on balancing probative value and prejudice. Building upon this initiative, the author offers an attempt at formulating a purposive structure for admissibility rules which would be of general application to both civil and criminal proceedings.
Avant de comprendre et d'évaluer les règles d'admissibilité de la preuve et avant de tenter de les structurer, il est essentiel de saisir quels sont leurs objectifs. Dans le présent article, l'auteur avance que les tribunaux évoluent vers une structuration de l'admissibilité de la preuve axée vers ces objectifs. Un aspect important de ce mouvement semble être l'importance croissante accordée à la nécessité de mesurer la valeur probante en regard du préjudice. $\dot{A}$ cette fin, l'auteur s'efforce de formuler une structure des règles d'admissibilité qui serait d'application générale à la fois dans la procédure civile et dans la procédure pénale.

\section{TABLE OF CONTENTS}

I. INTRODUCTION $\ldots \ldots \ldots \ldots \ldots \ldots \ldots \ldots \ldots \ldots$

II. THE BASICS: TERMINOLOGY AND

FUNDAMENTAL RULES $\ldots \ldots \ldots \ldots \ldots \ldots \ldots \ldots$

III. THE TWO ESSENTIAL ADMISSIBILITY QUESTIONS . . . . . 588

IV. PURPOSES SERVED BY ADMISSIBILITY RULES . . . . . . . .

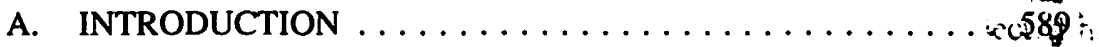

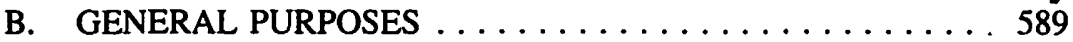

1. Balancing Flexibility and Providing Guidance ....... 589

2. Determination of the Truth $\ldots \ldots \ldots \ldots \ldots \ldots \ldots \ldots 50$

3. Fairness $\ldots \ldots \ldots \ldots \ldots \ldots \ldots \ldots \ldots \ldots \ldots$

(a) Fairness to the Proponent $\ldots \ldots \ldots \ldots \ldots \ldots \ldots 50$

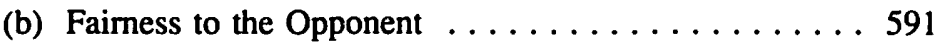

(c) Balancing Competing Claims to Faimess:

Probative Value Versus Prejudice .......... 591

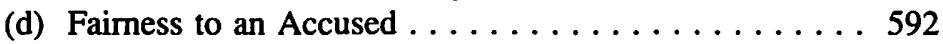

4. Trial Efficiency ................... 593

5. Maintaining Public Respect for the

Administration of Justice . . . . . . . . . . . . . 594

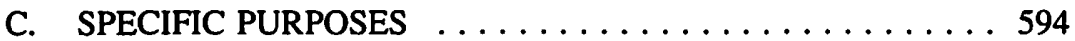

Associate Dean, Faculty of Law, University of Victoria. I would like to thank Leah R. Greathead and Roberta L. Reader (both LL.B., 1990, University of Victoria) for their research assistance. I would also like to thank my colleague, Professor Lym in R. Robinson, Q.C., and my sometime colleagues, Mr. Justice John C. Bouck of the Supreme Court of British Columbia, Professor J. Donald C. Galloway of the Faculty of Law, Queen's University, and Mr. Justice Roger P. Kerans of the Court of Appeal of Alberta, all of whom were visitors at the University of Victoria in 1989-90, for enduring various drafts of this article and providing me with many helpful comments. Of course, any remaining shortcomings in the article are nntirely my responsibility. 
1. The Voluntariness Requirement Applicable to a

Statement by an Accused to a Person in Authority . . . . . . 594

2. Exclusion of Illegally or Unfairly Obtained Evidence . . . . 595

3. Privileged Evidence . . . . . . . . . . . . . . . . . 597

4. Opinion Evidence . . . . . . . . . . . . . . . 598

V. QUESTION 1: IS THE OFFERED EVIDENCE

ADMISSIBLE? . . . . . . . . . . . . . . . . . . . . . . . . 599

A. INTRODUCTION: THE PURPOSIVE CONTEXT . . . . . . 599

B. FACTORS TO BE CONSIDERED . . . . . . . . . . 600

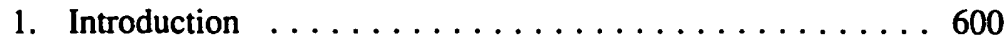

2. Form of the Offer ................. 600

3. Content of the Offer: An

"Admissibility Flowchart" . . . . . . . . . . . . . . 600

(a) An Admissibility Flowchart $\ldots \ldots \ldots \ldots 60 \ldots$

(b) Substantiating the Admissibility

Flowchart .................... 603

4. Timing of the Offer . . . . . . . . . . . . . 609

5. Party Offering .................... 610

6. Formal and Procedural Requirements

Affecting Admissibility ...............611

7. Cross-examination of Witness Versus

Extrinsic Evidence . . . . . . . . . . . . . 611

8. Nature of the Proceeding . . . . . . . . . . . 612

VI. QUESTION 2: IS THE EVIDENCE ADMISSIBLE

FOR SOME LIMITED PURPOSE? . . . . . . . . . . . . . . 612

A. INTRODUCTION . . . . . . . . . . . . . . 612

B. SOME EXAMPLES ..................6613

1. Hearsay Versus Original Evidence ............6613

2. Previous Conviction ................. 613

3. Previous Statement ... . . . . . . . . . . . 613

4. Character Versus Credibility of the Accused . . . . . . . 613

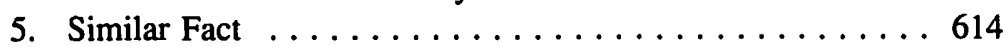

6. Statement by Co-party . . . . . . . . . . . . . 614

VII. NOTE ON WEIGHT GIVEN TO EVIDENCE . . . . . . . . . . . . . 614

VIII. GENERAL APPLICABILITY OF THE ANALYSIS . . . . . . . 615

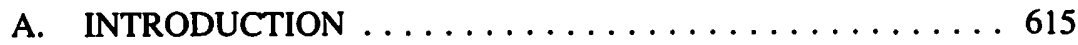

B. APPLICABLE TO BOTH CIVIL AND CRIMINAL

PROCEEDINGS ................... . . 615

C. APPLICABLE TO BOTH PARTIES . . . . . . . . . 616

D. APPLICABLE TO ALL FORMS OF OFFER . . . . . . . 616

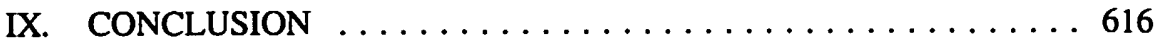


It is easier to suppose that [the rules of admissibility] originated in practical necessity than to give [them] logical place[s] in a symmetrical scheme of conceptions concerning evidence. - High Court of Australia, 1961.'

As is true with respect to the resolution of most, if not all, issues relating to the law of evidence, resort must be had, first and foremost, to its animating or first principles, for it is only with reference to these that the more specific rules of evidence can be understood and evaluated. - LaForest, J., 1988. ${ }^{2}$

\section{INTRODUCTION}

Lord Diplock once said that "the beauty of the common law" is that it "is a maze and not a motorway". ${ }^{3}$ Admissibility of evidence remains essentially a common law subject. With its many rules, exceptions and exceptions to the exceptions, it may indeed seem a maze. Its beauty, however, may not be apparent if practical experience and luck appear as important as analysis in confronting evidentiary questions.

In this article I attempt a purposive structuring of the admissibility of evidence. An organizing structure is required in order that admissibility rules may be learned and applied. A purposive structure, that is, a structure based on the purposes served by admissibility rules, facilitates analysis of evidentiary questions and evaluation of existing rules. Mechanical application of admissibility rules can be avoided and creativity in making submissions can be developed.

I am aware of the difficulties inherent in any attempt to structure a collection of common law rules. However, the constraint that some rules will never fit neatly and conveniently into any structure should not, in my view, deter one from making the attempt. The structure can serve its purposes in most cases, with anomalous rules being recognized as such.

I mention that this article is not a primer on the law of admissibility but, rather, offers an organizing structure for that law. I refer to specific admissibility rules only to the extent necessary to substantiate or illustrate my argument.

\section{THE BASICS: TERMINOLOGY AND FUNDAMENTAL RULES}

Claims are decided at trial by (1) the judge determining the applicable law, (2) the trier of fact (the jury or, if there is no jury, the judge) determining the facts, and (3) the trier of fact applying the law to the facts according to the judge's instructions. ${ }^{4}$ The judge

Ramsay v. Watson (1961), 108 C.L.R. 642 at 647 per the Court. The Court was actually referring only to res gestae. However, I could not resist generalizing this statement to introduce my attempt at structuring admissibility rules. The statement emphasizes the caution with which any attempt to structure admissibility rules must be approached.

2. Corbett v. The Queen, [1988] I S.C.R. 670 at 713 per LaForest, J. , dissenting.

3. Morris v. C.W. Martin \& Sons Ltd., [1966] 1 Q.B. 716 (C.A.) at 730 per Diplock, L.J.

4. In trial by judge and jury, in the judge's charge to the jury and in trial by judge alone, in the judge's instructions to himself or herself. 
determines the law on the basis of the parties' legal submissions. The trier of fact determines the facts on the basis of the evidence before it. There are two sorts of questions of fact which may have to be determined at trial.

First, "substantive questions of fact", as raised by the pleadings in a civil proceeding and the information, indictment and particulars in a criminal proceeding and the applicable substantive law, must be decided. Was the defendant negligent? Was the plaintiff contributorily negligent? If either was negligent, to what degree? Did the accused commit the proscribed act? Did the accused have the requisite intent? A substantive question of fact initially raised by the pleadings or substantive law may cease to be in issue (for example, through the formal admission of a party). Similarly, a fact not initially in issue may become an issue (for example, the accused may put his or her character in issue). If the parties agree on the facts, there are no questions of fact to be determined. Second, "questions of fact relating to credibility" arise whenever a witness testifies. The credibility of each witness is a question of fact. For convenience, I shall refer to "substantive questions of fact" as "substantive issues" and "questions of fact relating to credibility" as "credibility issues". Substantive and credibility issues are closely linked in that the trier of fact's findings on credibility issues affect its findings on substantive issues: the less credible the trier of fact finds a witness, the less effect that witness' testimony has in the trier's determination of the substantive issues. Distinguishing substantive and credibility issues raises some of the more difficult admissibility questions. ${ }^{5}$

I use "proponent" to refer to the party offering evidence and "opponent" to refer to the party opposing the offer. ${ }^{6}$

Offered evidence is "relevant" to a fact in issue if it tends to prove or disprove that fact. $^{7}$ Alternatively, relevant evidence has "probative value", although this latter term is typically used in the context of an inquiry as to the significance of the relevance. ${ }^{8}$ Offered evidence may be relevant to either a substantive issue or a credibility issue and to more than one issue. That is, offered evidence may have "multiple relevance". 9 If each of the relevancies involves an issue properly within the scope of the trier of fact's consideration, multiple relevance poses no particular difficulty.

Offered evidence relevant to an issue properly before the trier of fact may be of such a nature that the judge concludes that it will operate unfairly against the opponent. Evidence is said to be "prejudicial" if the judge fears that the trier of fact will succumb

s. See, for example, McInroy and Rouse v. The Queen (1978), 89 D.L.R.(3d) 609 (S.C.C.); R. v. McFadden (1981), 65 C.C.C.(2d) 9 (B.C.C.A.).

6. See, for example, 1 Wigmore on Evidence (Tillers rev.), section 19, page 844.

7. For example, Graat v. The Queen (1982), 144 D.L.R.(3d) 267 (S.C.S.) at 281. The Supreme Court of Canada has accepted Thayer's view that relevancy is a matter of "logic and experience, ... not ... of law" and rejected Wigmore's concept of "legal relevancy" as "something more than a minimum of probative value": Morris v. The Queen (1983), 7 C.C.C.(3d) 97 (S.C.C.) at 104 per Lamer, J., dissenting, but specifically agreed to by McIntyre, J., for the majority, at 98 .

8. Infra at text accompanying note 25 .

9. Cross, R. and C. Tapper, Cross on Evidence (7th ed.), (London: Butterworths, 1990) at 53. 
to the temptation to draw the wrong inferences from the evidence or, worse, that the evidence may inflame the trier of fact against the opponent to such an extent that it is indifferent to whether he or she has a fair trial. ${ }^{10}$ It is important to emphasize that prejudice does not arise merely because the offered evidence goes against the opponent's case: it must operate unfairly against the opponent."

Evidence is "admissible" if the trier of fact may consider it in determining the issues of fact before it. ${ }^{2}$ "Admissibility of evidence" is that body of law which determines what evidence may be considered by the trier of fact in deciding questions of fact. Questions of admissibility are questions of law, that is, questions within the exclusive jurisdiction of the trial judge. ${ }^{13}$

The fundamental admissibility rules are:

Rule 1. Evidence which is relevant to a substantive issue or credibility issue properly before the trier of fact is admissible. (This is often abbreviated simply to "relevant evidence is admissible".) ${ }^{14}$

Rule 2. Evidence which is not relevant (is "irrelevant") to either a substantive issue or credibility issue properly before the trier of fact is not admissible (is "inadmissible"). (In abbreviated form, "irrelevant evidence is inadmissible".) $)^{15}$

Rule 3. Evidence which is admissible under Rule 1 but which happens also to be relevant to an issue which the trier of fact cannot properly consider is admissible. That is, evidence admissible for one purpose is not rejected because it is inadmissible with respect to another purpose. However, the trier of fact either must or should be instructed as to the limited proper use of the evidence. ${ }^{16}$

There then follows a number of exclusionary rules under which relevant evidence is inadmissible for some policy reason external to the question of relevance ${ }^{17}$ and, in turn, exceptions to the exclusionary rules. ${ }^{18}$

\section{THE TWO ESSENTIAL ADMISSIBILITY QUESTIONS}

The two essential admissibility questions are:

(1) is the offered evidence admissible, and

\footnotetext{
10. R. v. Wood (1987), 56 Alta. L. R. (2d) 1 (C.A.) at 11.

11. The Queen v. Wray, [1971] S.C.R. 272; Potvin v. The Queen, [1989] 1 S.C.R. 525.

12. 1 Wigmore on Evidence (Tillers rev.), section 12, page 689: "Admissibility signifies that the particular fact ... is received by the tribunal for the purpose of being weighed with other evidence."

13. Schwartz v. The Queen, [1988] 2 S.C.R. 443.

14. Cloutier v. The Queen (1979), 48 C.C.C.(2d) 1 (S.C.C.) at 28.

15. Morris v. The Queen, [1983] 2 S.C.R. 190 at 201.

16. That is, in a trial by judge and jury, the trial judge must so charge the jury and in a trial by judge alone, the judge must so instruct himself or herself. See D.P.P. v. Boardman, [1975] A.C. 421 (H.L.) at 453; Cross, R. and Tapper C., supra, note 9 at 53.

17. $\quad$ R. v. Wood, supra, note 10 at 6; Cross, R. and Tapper, C. supra, note 9 at 60 , quoting Wigmore.

18. $\quad R$. v. Wood, supra, note 10 at 6 .
} 
(2) if the offered evidence is admissible, is it admissible at large or only for some limited purpose?

Since, as indicated, ${ }^{19}$ evidence is admissible only if it is relevant for some proper purpose, the two questions are related. Indeed, the purpose for which evidence is offered may be crucial in determining whether it is admissible. However, the second question is intended to focus on whether a cautionary instruction to the trier of fact is required.

The purposes served by admissibility rules are crucial to understanding them. Further, several decisions I made concerning the structure offered here were based on my evaluation of the purposes served by admissibility rules. Therefore, before proceeding to the offered structure, I canvass the purposes served by admissibility rules.

\section{PURPOSES SERVED BY ADMISSIBILITY RULES}

\section{A. INTRODUCTION}

Two introductory comments are necessary.

First, the purposes served by the various admissibility rules do not always co-exist in harmony. Indeed, quite the opposite is the case: conflicting purposes, resulting in conflicting rules, often must be confronted. For example, the fundamental rule that relevant evidence is admissible, which serves the purpose of enabling the proponent to persuade the trier of fact of his or her version of the facts, conflicts with each of the exclusionary admissibility rules, which have been created to serve other purposes. The question in situations involving such a conflict is which rule is paramount and will therefore prevail? Doctrine provides relatively clear answers in some cases. In others, no clear answer will be evident. Here, I suggest that explicit consideration of the conflicting rules' purposes is required.

Second, in the following two sections I canvass the purposes served by admissibility rules in general and some examples of specific purposes served by particular admissibility rules. This separation is somewhat artificial. However, I suggest it provides a helpful taxonomy.

\section{B. GENERAL PURPOSES}

\section{Balancing Flexibility and Providing Guidance}

As with all legal rules, admissibility rules serve the conflicting goals of certainty and flexibility. The law must be certain so as to provide guidance to prospective litigants. Yet it must be flexible in order, first, to be fair to particular litigants in individual cases and, second, to allow the law to evolve in accordance with changing societal perceptions 
of the interests served by it. ${ }^{20}$ A number of general purposes served by admissibility rules have been identified in decided cases. While arguably these are nothing more than various manifestations of the certainty and flexibility concerns, it is useful in constructing a purposive analysis of admissibility to list them specifically.

\section{Determination of the Truth}

The trial's objective of determining the truth and the historical fact that lay jurors were originally the principal trier of fact found the concern that admissible evidence be reliable or trustworthy to some minimal degree of assurance.

Rules concerning the competence of witnesses, authentication of documents and identification of real evidence are obvious manifestations of the trustworthiness concern. Similarly, the rationale underlying the exclusion of hearsay is the concern with the possibility of concoction or fabrication. ${ }^{21}$ Indeed, judges appear to be approaching a generalized statement that hearsay which is trustworthy is admissible. ${ }^{22}$ The concern with reliability was once dominant with respect to statements by an accused and, although due process concerns are now more significant in this area, reliability is still relevant. ${ }^{23}$

While the concern with admitting only reliable evidence is a fundamental one applicable to all offered evidence, mere reliability does not ensure admissibility. In some cases reliable and trustworthy evidence is inadmissible because a conflicting purpose served by another rule of admissibility prevails. Indeed, even admittedly true evidence may be excluded. For example, an accused may admit that a statement made to a person in authority is true, but it will nevertheless be inadmissible if it was made involuntarily. ${ }^{24}$

\section{Faimess}

(a) Fairness to the Proponent

The relevancy requirement is founded on the starting premise that a litigant should have a fair opportunity to present to the trier of fact all evidence which tends to prove his or her case and disprove the opponent's case.

22.

23.

24.

D.P.P. v. Boardman, supra, note 16 at 443.

Ratten v. The Queen, [1972] A.C. 378 (P.C.); Streu v. The Queen, [1989] 1 S.C.R. 1521 at 1529.

Ares v. Venner, [1970] S.C.R. 608; Public Trustee for Alberia v. Walker (1981), 122 D.L.R. (3d) 411 (Alta. C.A.); R. v. Khan (1988), 27 O.A.C. 142 (C.A.).

See infra at text accompanying notes 58-76.

An accused may be asked on the voir dire to determine the admissibility of his or her statement whether the statement is true: Declercq v. The Queen, [1969] 1 C.C.C. 197 (S.C.C.). But see Wong Kam-ming v. The Queen, [1980] A.C. 247 (H.L.). Of course, an accused may say that his or her statement is true when in fact it is not: for examples, see Kaufman: The Admissibility of Confessions (3rd ed.), 1979: Toronto; at 15-17. 
(b) Fairness to the Opponent

Evidence relevant to a fact properly in issue may operate unfairly against the opponent. That is, it may prejudice the chance that the opponent will have a fair trial.

\section{(c) Balancing Competing Claims to Fairness: Probative Value Versus Prejudice}

In some cases where evidence is both relevant to a fact properly in issue and prejudicial to the opponent, judges have determined admissibility by explicitly balancing the relevance of the evidence against its prejudice. The judge considers how relevant and how prejudicial the evidence is. The former is captured by referring to the "probative value" of the evidence. ${ }^{25}$ Such cases include the admissibility of illegally or unfairly obtained evidence (at least in the absence of any Charter violation), ${ }^{26}$ similar fact evidence, ${ }^{27}$ evidence of an accused's previous conviction elicited in cross-examination, ${ }^{28}$ and evidence concerning an accused's character in general. ${ }^{29}$ It must be emphasized, however, that the balancing of probative value and prejudice is a process and not a monolithic test. In particular, the probative value required for admissibility depends on the content of the evidence. Contrasting the different manifestations of the process applicable to similar fact evidence and illegally or unfairly obtained evidence provides an illustration.

If the Crown offers similar fact evidence, the starting point is that the evidence is generally inadmissible since it is a form of character evidence. However, such evidence may be admissible if its probative value "outweighs" its prejudicial value. McLachlin, J. recently stated: "The degree of probative value required to establish the admissibility of similar fact evidence will generally be high where the evidence is Crown evidence suggesting serious criminality or immorality. ${ }^{130}$ This generalized statement clarifies earlier uncertainty about the degree of probative value required. ${ }^{31}$ If either an accused or a party in a civil proceeding offers similar fact evidence, the degree of probative value required may be lower. ${ }^{32}$

In 1970, a majority of the Supreme Court of Canada held that illegally or unfairly obtained evidence offered by the Crown is admissible unless it is "gravely prejudicial to the accused" and "[its] probative force in relation to the main issue before the Court is trifling". ${ }^{33}$ Laskin, J. once characterized this as a "very narrowly confined" judicial discretion to exclude relevant evidence. ${ }^{34}$ Recent statements in the Supreme Court of

\footnotetext{
25. Supra at text accompanying note 8.

26. The Queen v. Wray, supra, note 11.

27. R. v. B.(C.R.) (April 12, 1990), (S.C.C.) [unreported].

28. Corbett v. The Queen (1988), 41 C.C.C. (3d) 385 (S.C.C.).

29. Morris v. The Queen (1983), 7 C.C.C. (3d) 97 (S.C.C.).

30. R. v. B.(C.R.), supra, note 27 at 10.

31. For example, in $R$. v. Wood, supra, note 10 at 13 , Kerans, J.A. referred to the "different inflections to be found in the judgments in Boardman".

32. $\quad R$. v. B.(C.R.), supra, note 27 at 10.

33. The Queen v. Wray, supra, note 11.

34. Hogan v. The Queen, [1975] 2 S.C.R. 574 at 595 per Laskin, J., as he then was, dissenting.
} 
Canada indicate a move away from this "restrictive approach". ${ }^{35}$ No longer will anything more than "trifling" probative value necessarily guarantee the admissibility of evidence despite its prejudicial effect: its probative value must outweigh its prejudicial effect. This development has probably been stimulated at least in part by the impact of the Charter ${ }^{36}$ and the Supreme Court's own admonition that common law develop consistently with Charter jurisprudence. ${ }^{37}$ For example, McLachlin, J. referred to such exclusion as follows and then went on to contrast it with the balancing process applicable to similar fact evidence: ${ }^{38}$

[The analysis] of similar fact evidence posits a test which is related to, yet distinct from the general rule that evidence is not admissible if its prejudicial effect outweighs its probative value: ... . That rule is an exclusionary rule applied to evidence which would otherwise be admissible. The reverse is the case with similar fact evidence. In determining its admissibility, one starts from the proposition that the evidence is inadmissible, given the low degree of probative force and the high degree of prejudice typically associated with it. The question then is whether, because of the exceptional probative value of the evidence under consideration in relation to its potential prejudice, it should be admitted notwithstanding the general exclusionary rule.

Her Ladyship's reference to "the general rule that evidence is not admissible if its prejudicial effect outweighs its probative value" is highly significant and, again, exemplifies similar recent statements in the Supreme Court. For example, LaForest, J. stated that evidence is to be excluded if it may unduly prejudice, mislead or confuse the trier of fact ${ }^{39}$ and Sopinka, J. characterized this as "the cardinal principle of our law of evidence".40

Thus, balancing probative value and prejudice is a process whose particular manifestation depends on whether the applicable starting point favours admission or exclusion. Further, the Supreme Court of Canada may be signalling that balancing probative value and prejudice applies to admissibility questions generally.

\section{(d) Faimess to an Accused}

The particular jeopardy in which an accused is placed in a criminal proceeding requires that special attention be given to ensuring that he or she receives a fair trial. Both the common law and the Charter recognize this concern.

The characterization is that of LaForest, J. in Potvin v. The Queen, supra, note 11 at 532. For example, exclusion of evidence under section 24(2) of the Charter, considered infra at text accompanying notes 67-76.

R.W.D.S.U. v. Dolphin Delivery Ltd., [1986] 2 S.C.R. 573 at 603; Bernard v. The Queen, [1988] 2

S. C. R. 833 at $850-855$.

R. v. $B(C . R$.$) , supra, note 27$ at 10.

Corbett v. The Queen, supra, note 28 at 416.

Morin v. The Queen (1988), 44 C.C.C.(3d) 193 (S.C.C.) at 216 per Sopinka, J., for the majority. Wilson, J. delivered a separate concurring judgment but specifically stated that she agreed with Sopinka, J.'s disposition of and reasoning on the character and similar fact issues within which Sopinka, J. agreed with LaForest, J.'s statement in Corbett. 
Examples of common law admissibility rules designed to secure faimess for the accused are the prohibition against the Crown leading evidence of the bad character of the accused $^{41}$ and the limits placed on cross-examination of an accused. ${ }^{42}$ Further, judges may be willing to admit exculpatory evidence offered by an accused while at the same time refusing to admit evidence of the same form and content which is inculpatory of the accused. Examples are the "sliding scale of admissibility" applicable to offers of similar fact evidence, under which an accused may not have to establish the same degree of probative value when offering such evidence as would the Crown, ${ }^{43}$ and what may be called the statement by an unavailable person against penal interest exception to the hearsay rule, which only permits the admission of evidence exculpatory of the accused. ${ }^{44}$

The constitutional entrenchment of the accused's right to a fair trial, guaranteed by the Charter ${ }^{45}$ has resulted in a renewed focus on ensuring faimess to the accused. ${ }^{46}$ In particular, some authority indicates that, while the general rule is still that both the accused and Crown are governed by the same admissibility rules, ensuring fairness to the accused may in practice require relaxing those rules when dealing with evidence offered by the accused. ${ }^{47}$

\section{Trial Efficiency}

Litigants wish to avoid unnecessarily lengthy proceedings and their attendant costs. The public, which bears the cost of providing judges and courtroom facilities, shares this interest. While the concern with trial efficiency underlies all admissibility rules to some extent, in some cases it comes to the forefront.

The obvious manifestation of the trial efficiency concern is the desire for timely resolution of disputes. For example, while the so-called collateral facts rule ${ }^{48}$ is sometimes explained as existing to prevent the substantive issues in trial being "buried beneath a mountain of irrelevancies", ${ }^{49}$ the rule is probably best explained in terms of a concern with trial efficiency. ${ }^{50}$ Similarly, the notice and other procedural requirements

41. Infra at text accompanying notes $129-131$.

42. R. v. Davison (1974), 20 C.C.C.(2d) 424 (Ont. C.A.).

43. $\quad R$. v. B.(C.R.) supra, note 27 at 10 , per McLachlin, J.

44. Lucier v. The Queen (1982), 65 C.C.C.(2d) 150 (S.C.C.).

45. Section $11(\mathrm{~d})$.

46. See, for example, Paciocco, D.M., Charter Principles and Proof in Criminal Cases, (Toronto: Carswell, 1987) at 124-132; Charles, W.H.R., T.A. Cromwell and K.B. Jobson: Evidence and the Charter of Rights and Freedoms, (Toronto: Butterworths, 1989) in particular, the constitutional recognition of the presumption of innocence has been central to this renewed focus on faimess. $R$. v. Williams (1985), 50 0.R.(2d) 321 (C.A.), leave to appeal to S.C.C. refused (1986), 50 0.R.(2d) $32 \ln$ (S.C.C.).

The Attorney-General v. Hitchcock (1847), 1 Ex. 91, 154 E.R. 38; Krause v. The Queen (1986), 29 C.C.C.(3d) 385 (S.C.C.) at 391-392.

Elliot, D.W. and S.L. Phipson, Manual of the Law of Evidence (12th ed.), (London: Sweet and Maxwell, 1987) at 119.

so. The Attorney-General v. Hitchcock, supra, note 48 at 44 per Rolfe, B.: "If we lived for a thousand years instead of about sixty or seventy, ... it might be possible ... to raise every possible inquiry as to the truth of the statements made. But I do not see how that could be; in fact, mankind find it to 
which may exist as prerequisites to admissibility, are founded on the concern for trial efficiency. ${ }^{.1}$

In other situations, the trial efficiency concern focuses not on the timeliness of dispute resolution but on adapting admissibility rules to the exigencies of the substantive law. For example, evidence may be "conditionally admitted"52 with the proponent indicating that the relevance of the evidence will be established. Notably, statements made in the presence of a party and offered as an adoptive admission ${ }^{53}$ or evidence offered under the co-conspirators exception to the hearsay rule ${ }^{54}$ may be so admitted.

\section{Maintaining Public Respect for the Administration of Justice}

Lord Hewart, C.J.'s famous words, that it is "of fundamental importance that justice should not only be done, but should manifestly and undoubtedly be seen to be done", are often repeated. ${ }^{55}$ This purpose has specifically been identified in the context of admissibility of evidence. In particular, it has been referred to in considering confession evidence $^{56}$ and evidence which is argued to have been obtained illegally or unfairly. ${ }^{57}$

\section{SPECIFIC PURPOSES}

1. The Voluntariness Requirement Applicable to a Statement by an Accused to a Person in Authority

There is no easy statement of the purposes underlying the voluntariness requirement and, as a result, no easy demarcation of the boundaries of involuntariness. ${ }^{58}$ Those purposes and boundaries appear to be in flux. Until recently, the principal concern espoused by the courts was ensuring the reliability of the accused's statement, that is, avoiding the conviction of the accused on the basis of a false statement. ${ }^{59}$ This narrow purpose resulted in a narrow scope of involuntariness: a statement was inadmissible only if obtained by a threat or promise held out to the accused by a person in authority. ${ }^{60}$ Adherence to the reliability purpose led to decisions holding that an involuntary statement which the accused said was true was inadmissible ${ }^{61}$ but that an involuntary statement subsequently verified as true by the discovery of real evidence was admissible to the

be impossible."

51. Infra at text accompanying notes 159-161.

52. Cross, R. and C. Tapper, supra, note 9 at 59-60.

53. R. v. Christie, [1914] A.C. 545 (H.L.).

s4. R. v. Baron and Wertman (1976), 31 C.C.C.(2d) 525 (Ont.C.A.); R. v. Carter, [1982] 1 S.C.R. 938;

R. v. Barrow (1987), 61 C.R.(3d) 305 (S.C.C.) at 338.

ss.

R. v. Sussex Justices, ex p. McCarthy, [1924] 1 K.B. 256 at 259; Brouillard v. The Queen (1985), I6 D.L.R. (4th) 447 (S.C.C.) at 450.

56. See, for example, Rothman v. The Queen, [1981] I S.C.R. 640.

37. See infra at text accompanying notes 65-76.

58. See Casswell, D.G., "The Law Reform Commission of Canada, the Proposed Canada Evidence Act and Statements by an Accused" (1985), 63 Can. Bar Rev. 322 at 325-328.

See, for example, Boudreau v. The Queen, [1949] S.C.R. 262 at 269.

The traditional formulation in Ibrahim v. The King, [1914] A.C. 599 (P.C.).

Declercq v. The Queen, supra, note 24; but, see Wong Kam-ming v. The Queen, supra, note 24. 
extent of the verification. ${ }^{62}$ These decisions are consistent with the reliability purpose and each other since in the former case the accused may be lying and the statement is false (unreliable) whereas in the latter case the statement is established as true (reliable). The fact that in either case the statement was obtained by inappropriate conduct on the part of a person in authority was not directly relevant to the question of admissibility.

While reliability has not become irrelevant, other concerns are now undoubtedly paramount. Even a highly reliable statement by an accused may be excluded in order to protect the right of an accused to remain silent, attempt to secure the proper conduct of persons in authority or prevent the administration of justice from being brought into disrepute. ${ }^{63}$ These concerns may conveniently be thought of as the "due process concerns" underlying the voluntariness requirement. ${ }^{64}$

\section{Exclusion of Illegally or Unfairly Obtained Evidence}

Illegally or unfairly obtained evidence may be excluded either at common law or under the Charter. However, the tests for exclusion - in particular, the significance of the probative value of the evidence - are different.

It is clear that the trial judge in a criminal proceeding has a common law discretion to exclude illegally or unfairly obtained evidence. Such exclusion has already been considered in the context of the balancing of probative value and prejudice. ${ }^{65}$ It is sufficient here to indicate that, while the Supreme Court may be moving towards expanding the common law scope for exclusion of illegally or unfairly obtained evidence, the starting point remains that relevant evidence is admissible. The prejudice which would be caused by admission must outweigh the probative value of the evidence. That is, the probative value of the evidence has crucial significance in the analysis.

Although not entirely free from doubt, it is probable that a trial judge in a civil proceeding has whatever discretion a judge in a criminal proceeding has to exclude illegally or unfairly obtained evidence. ${ }^{66}$ It is likely, however, that this discretion will in practice be more limited in a civil proceeding than in a criminal proceeding because the prejudice to a party required as a prerequisite to exclusion is less likely to arise than in the case of an accused who is in jeopardy of losing his or her liberty.

R. v. St. Lawrence, [1949] 0.R. 215 (H.C.).

See, for example, Horvath v. The Queen, [1979] 2 S.C.R. 376; Rothman v. The Queen, supra, note 56 640; R. v. Turgeon. [1983] i S.C.R. 308.

See Bushnell, S.I., "The Confession Cases: Erven, Horvath and Ward - Towards a Due Process Rationale" (1980), 1 Sup. Ct. L. Rev. 355.

Supra, at text accompanying notes 25-40.

In $R$. v. Wray, supra, note 11 at 303 , Hall, J., dissenting, stated that the trial judge's discretion to exclude illegally or unfairly obtained evidence "is a nule of very general application in civil as well as in criminal matters". Martland, J., for the majority, did not comment on civil proceedings. See Sopinka, J. and S.N. Lederman, The Law of Evidence in Civil Cases, (Toronto: Butterworths, 1974) at 335-347, for a review of the few civil cases on point and for reference to the equitable remedy of injunction to restrain the use of illegally or unfairly obtained evidence. 
Under section 24(2) of the Charter, offered evidence shall be excluded if it was obtained by means of a Charter violation and if its admission could bring the administration of justice into disrepute. ${ }^{67}$ The Supreme Court of Canada has held that a mere temporal as opposed to causal connection between the Charter breach and the obtaining of the evidence is probably sufficient ${ }^{68}$ and has listed a number of factors to be considered in determining whether admission could bring the administration of justice into disrepute. The Court has put these factors into three groups which take into account the effect admission would have on the fairness of the trial, the seriousness of the Charter violation and the effect exclusion would have on the repute of the legal system. ${ }^{69}$

While there is no doubt that the reliability of the offered evidence may be significant, reliability will sometimes give way to "due process" concerns similar to those relevant to the common law admissibility of an accused's statement. ${ }^{70}$ Unlike the common law approach to illegally or unfairly obtained evidence, the analysis under the Charter does not necessarily place much significance on the probative value of the evidence. LaForest, J., commenting on the factors to be considered on a section 24(2) exclusion application, recently stated that "the fairness of the process, and, in particular, its impact on the fairness of the trial" is "of cardinal importance"."7

The Supreme Court originally stated that while police misconduct in the investigatory process is a relevant factor, exclusion of evidence under the Charter is not a remedy for such misconduct. ${ }^{72}$ However, more recent indications from the Court are that the acceptability of police conduct in the particular case may be the crucial factor. ${ }^{73}$

Indeed, if the offered evidence is an accused's statement, the purposes underlying and the content of the common law requirement of voluntariness and the criteria for Charter exclusion appear increasingly similar. In particular, the previous common law rule under which an accused's involuntary statement was rendered admissible to the extent that it was verified by the subsequent finding of real evidence ${ }^{74}$ is probably no longer good law. ${ }^{75}$ The real evidence itself will, however, generally be admissible. ${ }^{76}$

"Would" in S. 24(2) of the Charter means "could": Collins v. The Queen, [1987] 1 S.C.R. 265 at 287-288; Ross v. The Queen, [1989] I S.C.R. 3 at 15.

Strachan v. The Queen, [1988] 2 S.C.R. 980 at 1000-1006.

Collins v. The Queen, supra, note 67; Strachan v. The Queen, supra, note 68 at 980; Ross v. The Queen, supra, note 67; Duarte v. The Queen, [1990] I S.C.R. 30; Greffe v. The Queen, [1990] 1 S.C.R. 755.

Supra at text accompanying notes 58-64.

Duarte v. The Queen, supra, note 69 at 59, writing for the majority. Emphasis mine.

Collins v. The Queen, supra, note 67 at 280-281.

Duarte v. The Queen, supra, note 69 at 59.

$R$. v. St. Lawrence, supra, note 62.

See, for example, Black v. The Queen, [1989] 2 S.C.R. 138, despite the subsequent finding of the knife, and $R$. v. Woolley (1988), 63 C.R. (3d) 333 (Ont. C.A.), in which, despite the subsequent finding of the car keys, the Crown did not even offer any of the accused's statements made after the police officer's threat.

See, for example, Greffe v. The Queen, supra, note 69 at 763 Dickson, C.J.C., dissenting, "[R]eal evidence, by its nature, if admitted will rarely have a detrimental impact upon adjudicative faimess." 


\section{Privileged Evidence}

Evidence which is privileged is not admissible, even if it is highly probative as part of the proponent's case and has little or no prejudicial effect on the opponent's case. The categories of privileged evidence are not founded on social concerns directly associated with the trial process. Rather, they are concerned with protecting interests of non-litigants. Indeed, the only connection among the rationales underlying the recognized categories of privilege is their protection of interests other than those of the litigants directly or the administration of justice indirectly.

The espoused purposes of several recognized categories of privilege demonstrate the variety of these categories. A communication between solicitor and client made in confidence and relating to the seeking or giving of legal advice is privileged at the instance of the client. ${ }^{71}$ It has been stated that the proper administration of justice depends upon clients being able to consult lawyers in confidence. ${ }^{78}$ Communications between husband and wife are privileged at the instance of the recipient spouse ${ }^{79}$ whether or not made in confidence. ${ }^{80}$ The purpose of this privilege is fostering matrimonial harmony. ${ }^{81}$ Public interest immunity, once referred to as Crown privilege, was formerly absolute. $^{82}$ Now it is generally a qualified privilege, with the court balancing the interests of the government and the litigant. ${ }^{83}$ In some cases, however, the privilege is absolute by statute. ${ }^{84}$ The rationale for such immunity is clear: in some cases, the need to maintain the secrecy of government information must prevail over the litigant's need to produce relevant evidence. ${ }^{85}$

The so-called privilege of a witness against self-incrimination is, at least as recognized in Canada, somewhat of a misnomer. At common law, a witness was not required to answer a question or produce a document which tended to incriminate him or her. ${ }^{86}$ This protection has been abrogated by legislation. However, none of the Canada

Solosky v. The Queen (1979), 50 C.C.C.(2d) 495 (S.C.C.) at 507, citing 8 Wigmore on Evidence (McNaughton Rev.), para. 2292; Descoteaux v. Mierzwinski (1982), 70 C.C.C. (2d) 385 (S.C.C.). Greenough v. Gaskell (1833), 1 Myl. \& K. 98, 39 E.R. 618 (Ch.), and Anderson v. Bank of British Columbia (1876), 2 Ch.D. 644, cited in Solosky v. The Queen, supra, note 77 at 506-507.

79. See Canada Evidence Act, R.S.C. 1985, c. C-5, s. 4(3) and analogous provisions in provincial Evidence Acts.

80. MacDonald v. Bublitz (1960), 31 W.W.R. 478 (B.C.S.C.).

81. Rumping v. Director of Public Prosecutions, [1964] A.C. 814 (H.L.). Sed quaere the status of this rationale in view of $R$. v. McGinty, [1986] 4 W.W.R. 97 (Y.T.C.A.) at 120-122 per McLachlin, J.A. Duncan v. Cammell Laird \& Co., [1942] A.C. 624 (H.L.).

83. Both at common law (Smallwood v. Sparling (1982), 141 D.L.R.(3d) 395 (S.C.C.); Carey v. The Queen in right of Ontario, [1986] 2 S.C.R. 637) and under most legislation (see, for example, Canada Evidence Act, R.S.C. 1985, c. C-5, ss. 37, 38; The Crown Proceeding Act, R.S.B.C. 1979, c. 86, s. 9).

8. For example, the Canada Evidence Act, R.S.C. 1985, c. C-5, s. 39.

85. For example, consider the wartime exigencies in Duncan v. Cammell Laird \& Co., supra, note 82.

86. See, for example, R. v. Simpson, [1943] 2 W.W.R. 426 (B.C.C.A.) at 434; In re Westinghouse Elec. Corp. (No. 2), [1977] 3 W.L.R. 492 (C.A.) at 494-496. 
Evidence $A c t,{ }^{87}$ the provincial Evidence $A c t s^{88}$ or the Charter $^{89}$ permits a witness to refuse to testify on the basis that the evidence may be self-incriminatory. Rather, they limit the use of his or her testimony in subsequent proceedings. ${ }^{90}$ Thus, the litigant's interest in eliciting the evidence is recognized as paramount to the witness' interest in not disclosing the self-incriminatory evidence. An accused, however, does have the right not to testify at trial and this right is sometimes referred to as the privilege of the accused against self-incrimination. ${ }^{91}$

\section{Opinion Evidence}

An opinion is an inference from observed facts. In practice, however, the distinction between observed fact and opinion is often a difficult one. ${ }^{92}$ There is not one rule governing admissibility of opinion evidence but rather an approach involving both exclusionary and inclusionary aspects. The inclusionary aspects of the opinion rule are that an expert may give opinion evidence on matters within his or her field of expertise and a non-expert may give opinion evidence on matters within common knowledge, provided that in either case the opinion evidence is helpful to the trier of fact. This is particularly so in the case of expert opinion, where the purpose of the expert's evidence is to provide the trier of fact with a "ready-made inference"..$^{93}$ The exclusionary aspects of the rule, which are merely the converse of the inclusionary aspects, are that an expert may not give opinion evidence on matters outside his or her field of expertise and a non-expert may not give opinion evidence on matters calling for expertise. ${ }^{94}$ In summary, it is more accurate to say that opinion evidence is admissible if it would be

R.S.C. 1985 , c. C-5, s. 5(1).

For example, The (British Columbia) Evidence Act, R.S.B.C. 1979, c. 116, s. 4.

Section 13.

Commenting on the effect of the Canada Evidence Act, R.S.C. 1985, c. C-5, s. 5(1) and analogous provincial legislation, McWilliams, P.K., Canadian Criminal Evidence (looseleaf 3rd ed.), page 35-30, section 35:10410, bluntly states that they abolish the privilege against self-incrimination of a witness. I am deliberately glossing over the significant differences in the wording of and therefore the scope of application of the various Evidence Acts and the Charter since those distinctions are irrelevant to the main point made here, that is, that a witness is still required to testify; in this regard, however, see, for example, McWilliams, P.K.: Canadian Criminal Evidence (looseleaf 3rd ed.), page 35-34, section 35:10440.

1. A suspect under investigation has the right to remain silent and the accused at trial does not have to testify. Lamer, J., in Rothman v. The Queen, supra, note 56 at 682-684 characterized this common law right as the exercise of the general right not to speak unless obliged to do so by law rather than as a manifestation of the privilege against self-incrimination. However, Schiff, S., Evidence in the Litigation Process (3d), (Toronto: Carswell, 1988) at 946-947 states that the right of the accused not to testify "is not inappropriately described as the ... 'privilege against self-incrimination'". This right is now guaranteed by section 11 (c) of the Charter. However, the privilege of the accused against self-incrimination, both at common law and under the Charter, is strictly testimonial: Marcoux and Solomon v. The Queen, [1976] I S.C.R. 763; R. v. Altseimer (1982), 38 O.R. (2d) 783 (C.A.). Sed quaere in view of Ross v. The Queen, supra, note 67.

Graat v. The Queen, [1982] 2 S.C.R. 819 at 835.

Abbey v. The Queen, [1982] 2 S.C.R. 24 at 42; Lavallee v. The Queen, [1990] 1 S.C:R. 852 at 889 per Wilson, J.

Sherrad v. Jacob, [1965] N.I. 151 (C.A.) at i57-158; R. v. Fisher (1961), 34 C.R. 320 (Ont. C.A.). 
helpful to the trier of fact ${ }^{95}$ or, perhaps, if it represents a "compendious statement of fact". ${ }^{96}$ The latter formulation almost defines away an objection to opinion evidence by stating that the offered evidence is in substance fact, not opinion, and returns us to the starting point that fact and opinion are in practice often difficult to distinguish.

The traditional rationale underlying the treatment of opinion evidence is that the roles of witness and trier of fact be kept distinct, the witness testifying as to observed facts and the trier of fact making findings of fact, including making inferences from primary observed fact if necessary. A manifestation of this concern was the "fetish"97 of rejecting opinion evidence on the ultimate issue which the trier of fact had to determine on the basis that to admit such evidence would permit the witness to "usurp" the function of the trier of fact. Excluding evidence on this basis has now been rejected, since the trier of fact is entitled to accept or reject the opinion whether it happens to be on the ultimate issue or not. ${ }^{98}$

\section{QUESTION 1: IS THE OFFERED EVIDENCE ADMISSIBLE?}

\section{A. INTRODUCTION: THE PURPOSIVE CONTEXT}

Recent decisions indicate that a purposive analysis should be used in deciding admissibility questions. ${ }^{99}$ There are at least three aspects to the purposive analysis of an admissibility question.

First, the purpose served by an admissibility rule must be constitutional. The rule may be unconstitutional and, therefore, inapplicable, if it is ultra vires legislation. While determination of the vires of legislation may sometimes be difficult in practice, in theory the analysis is straightforward. ${ }^{100}$ Alternatively, an admissibility rule may be unconstitutional either because it violates a Charter guaranteed right or freedom in general or because its application to the facts of a particular case would result in such a violation. An example of the former is the Supreme Court of Canada's holding that the reverse onus provision of the Narcotic Control Act was unconstitutional. ${ }^{101}$ An example of the latter is the common law rule under which relevant but illegally obtained evidence is admissible regardless of the nature of the illegality. Such evidence may in the particular circumstances be excluded under section 24(2) of the Charter. ${ }^{102}$

R. v. Fisher, supra, at 340; Graat v. The Queen, supra, note 7 at 834.

Graat v. The Queen, supra, note 92 at 840.

Graat v. The Queen, supra, note 92 at $836-837$ per Dickson, J.

Ibid. at 833. It is important to emphasize that this case involved non-expert opinion evidence. To date, the Supreme Court has not stated that the same rule applies in the case of expert opinion evidence but it would seem surprising if it did not. Centainly other courts have so held in cases involving expert opinion evidence. See, for example, R. v. Fisher (1961), 34 C.R. 320 (Ont. C.A.) at 340 .

99. For example, Rothman v. The Queen, supra, note 56; Solosky v. The Queen, [1980] I S.C.R. 821; R. v. McGinty, supra, note 81 .

Marshall v. The Queen, [1961] S.C.R. 123.

R. v. Oakes (1986), 50 C.R.(3d) 1 (S.C.C.).

Supra at text accompanying notes 67.76 . 
Second, since admissible evidence must be relevant to a fact properly in issue, the proponent's purpose in offering the evidence must be considered. ${ }^{103}$

Third, and in particular in situations where authority does not provide clear guidance on the admissibility question, consideration of the social policies served by the admissibility rules in question is required. ${ }^{104}$

\section{B. FACTORS TO BE CONSIDERED}

1. Introduction

The following factors are relevant in determining whether offered evidence is admissible. A factor may be determinative in one case and of little or no significance in another. However, since each factor may be crucial in any given case, all factors should be considered with respect to every offer of evidence.

\section{Form of the Offer}

Minimal reliability is a prerequisite to admissibility for all forms of offered evidence. ${ }^{105}$ This concern is encompassed by the rubrics of competence of witnesses, authentication of documents, identification of real evidence, and helpfulness of other demonstrative evidence. ${ }^{106}$ The judge must determine that a witness possesses at least minimal ability to testify, that there is some evidence from which the trier of fact might infer that documentary and real evidence is what it purports to be or that other demonstrative evidence accurately represents what it purports to represent.

\section{Content of the Offer: ${ }^{107}$ An "Admissibility Flowchart"}

\section{(a) An Admissibility Flowchart}

The content of the offer, that is, the statement or representation contained in the evidence, is often the principal factor determining whether it is admissible. Consideration of the content of the evidence subsumes questions such as whether the evidence is relevant and whether it is hearsay, opinion, character, confession or the subject of a

\footnotetext{
103. Supra at text accompanying note 14.

10. Supra at text accompanying note 99.

105. 1 Wigmore (Tillers rev.), section 17, at 758, uses the expression "form of the offer" to distinguish among testimony, documents and other offers.

106. The expressions "real evidence", "document" and "demonstrative evidence" are not defined terms of art, but rather convenient expressions to identify various forms of offered evidence. For present purposes, I use "real evidence" to refer to any physical object offered for inspection by the trier of fact, "document" to refer to anything on which there is writing, whether offered for a testimonial or circumstantial purpose, and "demonstrative evidence" to refer to demonstrations and visual representations other than real evidence and documents.
}

107. 1 Wigmore on Evidence (Tillers rev.), section 17, at 768, uses the expression "tenor of the offer" to refer to the "specific contents" of the offered evidence. 
privilege. I offer the following admissibility flowchart for considering the content of evidence.

Whether evidence is admissible may be determined by following the various steps in the flowchart, starting at the top and working down. If evidence is excluded as inadmissible at any stage of the process, that is the end of the matter. If evidence is not excluded at any stage in the flowchart, then the following stages must be considered. For example, offered evidence may be both irrelevant and hearsay not encompassed by an exception to the hearsay rule. Thus, the evidence is inadmissible on two grounds. Either will suffice to render it inadmissible. Considering the offered evidence in the order suggested by the flowchart would result in the evidence being excluded at the relevancy stage. That the evidence happens also to be inadmissible hearsay is superfluous. On the other hand, consider evidence which is relevant but inadmissible hearsay. The evidence passes the relevancy stage but is excluded at the hearsay stage. I also indicate that the flowchart is not intended to suggest that the various admissibility questions are considered in isolation one from another. Counsel fashioning submissions either supporting or opposing admission and a judge determining an admissibility question will no doubt want to look ahead and consider all possible arguments and their relationships before making submissions or a ruling. 


\section{ADMISSIBILITY FLOWCHART}

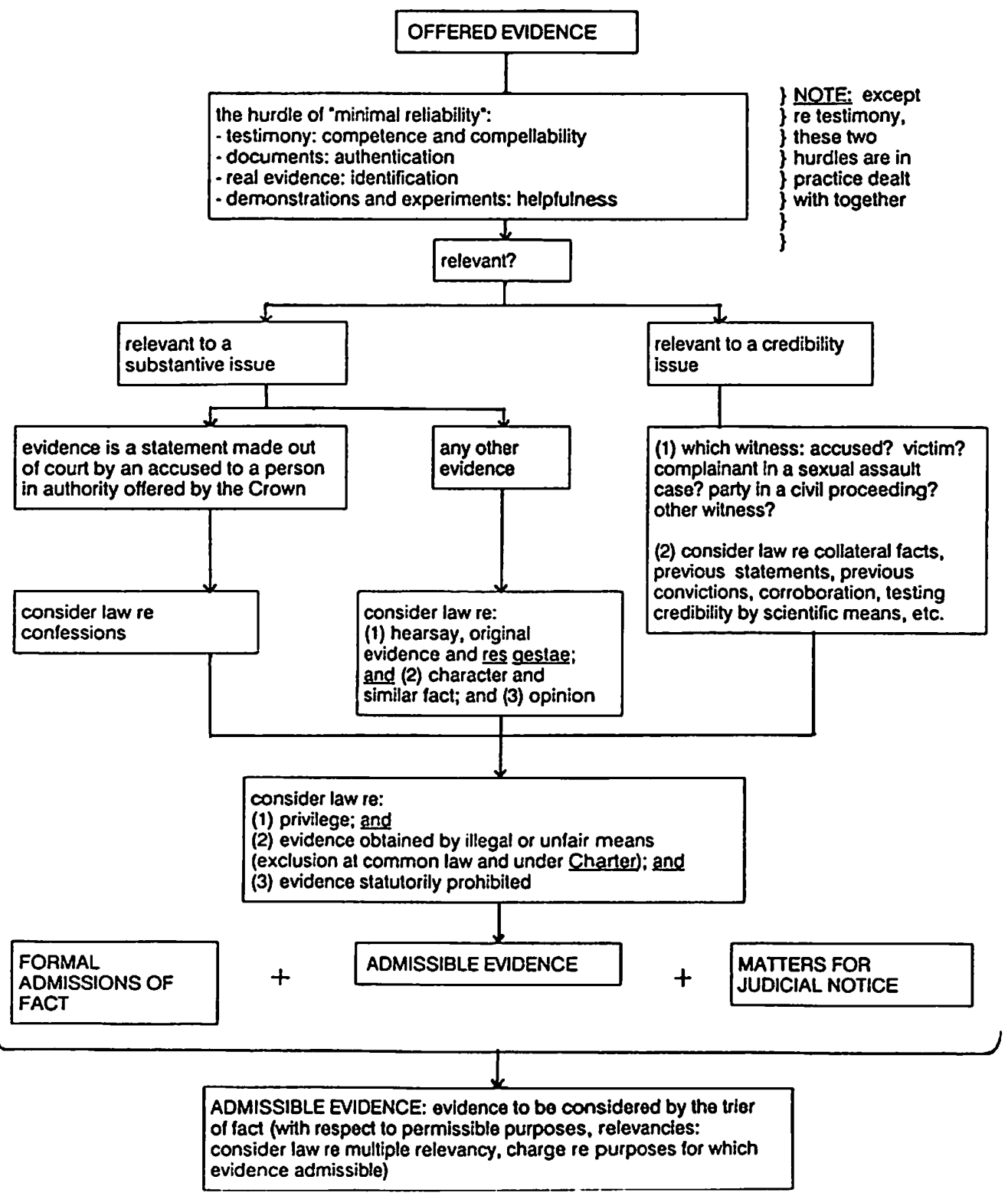




\section{(b) Substantiating the Admissibility Flowchart}

Admissibility of evidence is not a logical science but rather a collection of practical solutions to questions posed by offers of evidence. Therefore, any attempt to structure and schematically represent admissibility issues must be approached with caution and a healthy degree of scepticism. Few rules of admissibility fit neatly into any organizing structure. Some fit appropriately at more than one stage of the admissibility analysis. Others do not fit very well anywhere. Furthermore, while an organizing structure should be as logical as decided authority permits, it must not appear to state dogmatically that "here is when you consider this point". Rather, it simply organizes the consideration of issues so that all are deait with at some stage. Finally, an organizing structure should avoid being overly idiosyncratic and should be substantiated by reference to authority.

In this section I attempt to explain why I have organized the content-focused aspects of admissibility rules as I have done. Also, I indicate some of the difficult overlaps between various admissibility rules.

Judicial statements about the organization of admissibility rules are rare and usually refer to the basic requirement of relevancy, indicate that there are exclusionary rules under which relevant evidence is not admitted, and then stop. ${ }^{108}$ Some refer to there being exceptions to the exceptions. ${ }^{109}$ For this reason, relevancy must come at the start, or very near to it, of any organization of the admissibility rules.

As already indicated, if offered evidence is not relevant to any issue properly before the trier of fact, it is inadmissible. ${ }^{110}$ In some cases, it is likely that a judge rules that offered evidence is irrelevant and therefore inadmissible even though as a matter of logic the evidence does tend, to some minimal degree, to prove or disprove a fact in issue. The judge may be motivated by the concern that the trial not be overly lengthy. The judge weighs the minimal probative value of the evidence against the time that it would take to lead and concludes that on balance the evidence should not be admitted.

Except in the case of testimony, separating relevance and minimal reliability is something of a chicken-and-egg exercise. In practice the relevance of offered evidence and establishing some basis for the judge to find that it has minimal reliability are accomplished simultaneously. For example, a witness testifies as to the existence of a written agreement, a document is shown to the witness and the witness states that the document is the agreement in question. Both relevancy and authentication have been established. However, in the case of testimony, the witness' competence and the relevance of what he or she has to say are quite distinct. In the absence of anything raising a concern about competence, competence is assumed. However, if competence is a concern, an inquiry into the witness' competence is undertaken before the witness testifies. Since this inquiry into competence precedes consideration of whether the 
witness' testimony is relevant, I have put minimal reliability before relevancy. Determining whether a competent witness is compellable also arises before relevance is considered.

Claims to privilege also arise before relevance is considered. However, issues of privilege do not determine whether a witness will testify generally but rather focus on the admissibility of particular evidence. Thus, the competence and compellability of witnesses are analogous to authentication and identification in that they concern whether the offered form of evidence, as opposed to its content, may be considered, whereas questions of privilege focus on the offered evidence's content. For this reason, and another considered below, ${ }^{111}$ I have put privilege later in the admissibility flowchart. ${ }^{112}$

I then divided the admissibility flowchart into evidence relevant to a substantive issue and that relevant to a credibility issue, since different rules apply to each category. For example, a witness' testimony that "the traffic light was red" in a typical motor vehicle case is relevant to the substantive issues in trial. Evidence that the witness' view of the traffic light was hampered by a steamed up windshield is relevant to the witness' credibility. However, multiple relevance problems may arise in which offered evidence is relevant to both a substantive and a credibility issue. ${ }^{113}$ In such cases, compromise solutions are found. The classic example occurs when an accused testifies but has not put character in issue. The credibility of the accused is in issue but not his or her character. The compromise arrived at in this case is that an accused may be cross-examined with respect to previous misconduct or discreditable associations only if it relates to the charge being tried. ${ }^{114}$

I now turn to the organization of the admissibility flowchart with respect to evidence relevant to a substantive issue. Evidence of an out of court statement made by an accused to a person in authority offered in evidence against the accused (often for convenience still referred to by the misnomer, "confession") $)^{115}$ is admissible only if the Crown establishes that the statement was made freely and voluntarily. ${ }^{116}$ In particular, if the statement was not made voluntarily, it is not admissible even if it fits the criteria of res

III. Infra at text between notes 141 and 142 .

112. Infra at text between notes 141 and 142. For an example of the importance of distinguishing among competence, compellability and privilege, see $R$. v. McGinty, supra, note 81 .

113. Supra at text accompanying note 9.

114. For excellent discussions of this problem, see $R$. v. Davison, supra, note 42 at $441-444 ; R$. v. McFadden (1981), supra, note 5 at 12-13.

115. "Confession", with its inculpatory connotation, is a misnomer since the voluntariness requirement applies to any statement made by an accused out of court to a person in authority, whether inculpatory or exculpatory: Piche v. The Queen, [1971] S.C.R. 23 at 25-26; Erven v. The Queen (1978), 6 C.R.(3d) 97 (S.C.C.) at 101; McWilliams, P.K: Canadian Criminal Evidence (looseleaf 3rd ed.), page 15-5, paragraph 15:10000.

116. Erven v. The Queen, supra, note 115 at 103 . The onus on the Crown is proof beyond a reasonable doubt: Park v. The Queen ('ng1), 59 C.C C. (2d) 385 (S.C.C.) at 387. 
gestae. ${ }^{117}$ More generally, confession evidence is not a category of hearsay. ${ }^{118}$ That is, the voluntariness requirement is the exclusive test for determining whether such evidence is admissible. Given this exclusivity, I have separated confession evidence from all other evidence relevant to a substantive issue.

I next explain several organizational decisions concerning evidence which is relevant to a substantive issue but is not confession evidence. First, I placed res gestae in the flowchart together with hearsay and original evidence. It is trite that hearsay is evidence of an out of court statement offered to prove its truth whereas original evidence is evidence of an out of court statement offered for any other purpose. ${ }^{11}$ Further, evidence admissible as part of the res gestae may be admissible either as hearsay or as original evidence. ${ }^{120}$ Thus, the placing of res gestae together with hearsay and original evidence is not terribly contentious. However, an accused's out of court statement to a person in authority may be admissible as part of the res gestae if offered by the accused. ${ }^{121}$ For this reason I included the admittedly superfluous words "offered by the Crown" in the flowchart's reference to confession evidence.

I turn now to my positioning of character and similar fact along with hearsay and opinion. The usual starting point in an analysis of either hearsay or opinion is the statement of an exclusionary rule. Hearsay is inadmissible. ${ }^{122}$ Opinion evidence is inadmissible. ${ }^{123}$ Alternatively, reference is made to the "rule against hearsay" and the "rule against opinion evidence". However, a great deal of hearsay and opinion evidence is admissible. There are numerous exceptions to the hearsay rule. Similarly, it is possible to characterize admissible opinion as exceptions to an exclusionary starting point. However, in my view a more accurate representation is one which recognizes a mix of exclusionary and inclusionary aspects as the starting point. Thus, it seems to me that while an exclusionary formulation of either hearsay or opinion may serve as a convenient practical starting point, it is better to think of the treatment of hearsay and opinion as follows. Hearsay or opinion evidence offered to prove a substantive issue may or may not be admissible. Similarly, character or similar fact evidence offered to prove a substantive issue may or may not be admissible. This last statement is one with which we are probably more familiar. My point here is that it seems to me that all of hearsay;

Erven $\mathrm{v}$. The Queen, supra, note 115 at 110 . I mention that for present purposes it is not necessary to confront the difficult questions of precisely what the criteria for admissibility as "part of the res gestae" currently are or whether, indeed, the hoary doctrine of res gestae has been superseded by a newly formulated "spontaneous declaration" exception to the hearsay rule: see $R$. v. Clark (1983), 7 C.C.C. (3d) 46 (Ont. C.A.); R. v. Slugoski (1985), 17 C.C.C. (3d) 212 (B.C.C.A.); R. v. Khan, supra, note 22.

118. This is because the voluntariness requirement applies to both inculpatory and exculpatory statements and regardless of the trial purpose of the Crown in offering the evidence: Piche v. The Queen, supra, note 115; Erven v. The Queen, supra, note 115 at 101 . In particular, the Crown may not be offering the statement for its truth. See Casswell, D.G., supra, note 58 at 336-337. Subramaniam v. D.P.P., [1956] 1 W.L.R. 965 (P.C.); R. v. Abbey, [1982] 2 S.C.R. 24, 68 C.C.C. (2d) 394.

120. Ratten v. The Queen, supra, note 21.

121. Infra at text accompanying note 153.

122. Subramaniam v. D.P.P., supra, note 119; R. v. Abbey supra, note 93.

123. Graat v. The Queen (1982), supra, note 7. 
opinion, character and similar fact may conveniently be dealt with as essentially the same type of rule. Thus, they should be considered at the same stage in the admissibility flowchart.

In considering admissibility rules dealing with character and similar fact, it is essential from the outset to focus on whose character the offered evidence concerns and for what purpose it is said to be relevant. Since it is difficult to separate evidence of a person's credibility from his or her character generally, there is some overlap here with the sertion of the flowchart dealing with evidence relevant to a credibility issue.

The credibility of a witness who is not a party to the proceeding may be tested by cross-examination with respect to discreditable conduct and associations unrelated to the subject matter of his or her testimony. ${ }^{124}$ That is, evidence of a witness' character is in general admissible because it is relevant to his or her credibility. If the witness is a party in a civil proceeding, it would likewise seem that his or her character may be explored fully as being relevant to credibility. ${ }^{125}$ If the witness is an accused, however, and if his or her character is not in issue, he or she may not be cross-examined on previous misconduct or discreditable association unrelated to the charge being tried unless such evidence is directly relevant to prove the falsity of the accused's evidence. ${ }^{126}$ If the witness is a complainant in a sexual assault case, there are statutory limitations on cross-examination as to his or her sexual activity. ${ }^{127}$ In short, evidence concerning the character of a witness may be admissible in cross-examination of the witness depending on who the witness is. Finally, while evidence of a witness' character which is relevant to his or her credibility will typically be collateral to the main issues in trial, if it is noncollateral then extrinsic evidence will also be admissible to contradict the witness.

Evidence concerning the character of a non-witness may be admissible if that person's character is in issue. Examples may include the plaintiff in a defamation action, parents involved in a custody dispute, the victim of an alleged crime and a person who is not charged with a crime but whom the accused says committed the crime alleged against the accused. ${ }^{128}$ Similarly, although the Crown is generally not permitted to lead evidence of the bad character of the accused, ${ }^{129}$ the accused's character may be a proper issue if made so by express statutory provision ${ }^{130}$ or to rebut evidence led by the accused of his or her good character. ${ }^{131}$

124. R. v. Davison, supra, note 42 at $443-444$.

123. Deep v. Wood Gundy Lid. (1983), 33 C.P.C. 256 (Ont.C.A.). However, it was stated that in a trial by judge and jury, the judge has a discretion to restrict cross-examination of a party who testifies in order to prevent unfaimess to the party.

126. $R$. v. Davison, supra, note 42 at 444.

127. Criminal Code, R.S.C. 1985, c. C-42, s. 276.

128. See, for example, R. v. McMillan (1975), 23 C.C.C. (2d) 160 (Ont. C.A.), affirmed [1977] 2 S.C.R. 824; $R$. v. Scopelliti (1981), 63 C.C.C. (2d) 4 (Ont. C.A.).

129. Makin v. The Attorney-General for New South Wales, [1894] A.C. 57 (P.C.) at 65; Morris v. The Queen, [1983] 2 S.C.R. 190 at 201-202; R. v. D(L.E.), [1989] 2 S.C.R. 111 at 120 per Sopinka, J.

130. For example, Criminal Code, R.S.C. 1985, c. C-42, s. 360.

131. R. v. Rowton (1865), Le. \& Ca. 520, 169 E.R. 1497 (C.C.); R. v. McFadden (1981), supra, note 5. 
Similar fact evidence is undoubtedly character evidence but is admitted if its probative value with respect to an issue properly before the trier of fact outweighs its prejudicial value. ${ }^{132}$

In summary, then, whether offered character or similar fact evidence is admissible depends upon to whose character the evidence relates. In some cases admissibility depends simply upon whether the evidence is relevant to an issue properly before the trier of fact, a hurdle applicable to all offered evidence. In other cases admissibility depends additionally on how relevant the evidence is: does its probative value outweigh its prejudicial effect?

Some writers treat character and similar fact evidence almost exclusively as an example of the relevancy requirement. ${ }^{133}$ In my view, this formulation fails adequately to highlight the importance of the specific exclusionary rules dealing with certain evidence of character, notably evidence of the accused's bad character. Others take a course recognizing that, while the crucial question is relevance, certain exclusionary rules must also be kept at the forefront of consideration. ${ }^{134}$ I prefer an approach which highlights the importance of the exclusionary aspects of the treatment of character and similar fact evidence. Kerans, J.A. made this point when he referred to there being an "exclusionary rule" which operated on evidence offered as similar fact and stated: ${ }^{135}$

This by definition is not a restatement of the relevance rule, but expresses the idea that, for good and just reasons, some evidence that tends to prove something should nevertheless not be put before the trier of fact. That there indeed is an exclusionary rule, unrelated to the question of relevance, that operates upon similar facts seems beyond dispute.

I therefore grouped consideration of character and similar fact together with hearsay and opinion. However, before leaving similar fact, I mention that such evidence may be relevant to both a substantive issue and a credibility issue. For example, similar fact evidence concerning a party's conduct may be relevant to his or her credibility if he or she has testified. ${ }^{136}$

As a final point with respect to admissibility rules dealing with evidence which is relevant to a substantive issue but is not a confession, I stress that if such evidence is

132. D.P.P. v. Boardman, supra, note 16; Sweitzer v. The Queen, [1982] 1 S.C.R. 949; R. v. Robertson, [1987] 1 S.C.R. 918; R. v. D.(L.E.), supra, note 129.

133. For example, Delisle, R.J., Evidence: Principles and Problems (2d ed.) (Toronto: Carswell, 1989) at 37-71.

134. For example, Schiff, S., supra, note 91 at 775 , takes a middle course in dealing with character and similar fact: "The meaning of 'relevancy' and the nature of circumstantial evidence [have been] discussed... . Following ... was a brief canvass of the trial judge's general authority to exclude an item of relevant evidence after weighing probative value against counterbalancing factors. ...Here we focus largely on certain kinds of circumstantial evidence directed to particular issues where hard exclusionary rules based on the counterbalancing factors have been superimposed on the general judicial authority." (emphasis mine)

133. $R$. v. Wood, supra, note 10.

136. See, for example, R. v. McNamara No. 1) (1981), 56 C.C.C. (2d) 193 (Ont. C.A.) at 352. 
inadmissible under any of the hearsay, opinion or character evidence rules, it is excluded. For this reason I have emphasized the word "and" connecting the listing of these rules in the flowchart. A difficult question is whether such evidence is admissible if it satisfies the res gestae requirements even if it would otherwise have been excluded as inadmissible character or opinion evidence. ${ }^{137}$ (Evidence admissible as part of the res gestae is admissible even if hearsay. ${ }^{138}$ An involuntary confession is not rendered admissible by satisfying the res gestae requirements. ${ }^{139}$ )

Evidence relevant to credibility has already been considered in passing in the context of distinguishing such evidence and evidence relevant to a substantive issue. ${ }^{140}$ Again, some writers treat some evidence relevant to credibility as essentially an example of a relevancy problem. Evidence of an accused's previous conviction brought out in crossexamination is an example. ${ }^{141}$ As with character and similar fact evidence, my view is that the special problems inherent in evidence of a previous conviction offered as relevant to credibility (and, indeed, other such evidence) warrant placing consideration of such evidence in a separate position in the admissibility flowchart rather than subsuming it into the general relevancy requirement.

The policy concerns underlying the admissibility rules considered so far focus largely on fairness to the litigants at trial. For example, the relevancy requirement is based on the belief that a litigant should have a fair opportunity to prove his or her case by being able to put any relevant evidence before the trier of fact. The hearsay rule is based on the concern that a litigant have a fair opportunity to test through cross-examination the trustworthiness of the opponent's evidence. Evidence concerning the bad character of an accused is generally inadmissible to prevent unfairness to the accused. Opinion evidence may be inadmissible since it is inherently difficult for the opponent to test its value. There are exceptions to this generalization. Notably, the treatment of confession evidence focuses both on faimess to the accused and on due process concerns not directly related to the trial process.

Separation of policies focused directly on trial faimess and those focused on other policy concerns is somewhat artificial since any admissibility ruling affects the perceived fairness of the trial process regardless of the specific policy underlying the ruling. However, I have grouped together consideration of privileged evidence, evidence illegally or unfairly obtained and statutorily prohibited evidence because it seems to me that the rationales underlying the admissibility rules on these topics do not focus directly on securing a fair trial for the litigants but rather upon social policies only indirectly related to the trial process.

141. Delisle, J.D., supra, note 133 at 26-35, reproducing portions of Corbett v. The Queen (1988), 64 C.R. (3d) 1 (S.C.C.). 
Exclusion of privileged evidence and statutorily prohibited evidence fit quite well into this analysis. A litigant's desire to lead relevant evidence may be defeated by another's claim to privilege. The person claiming privilege need not have any interest in the outcome of the trial. Similarly, statutorily prohibited evidence is unavailable to a litigant to prove his or her case. ${ }^{142}$

Exclusion of illegally or unfairly obtained evidence does not fit quite so well into this analysis. In the case of exclusion under section 24(2), as considered already, it is not terribly contentious to assert that both immediate trial concerns and social purposes not directly related to the trial process are served. ${ }^{143}$ At common law, however, the principle concern was the reliability of the offered evidence. How it had been obtained was essentially irrelevant. Recent developments suggest, however, that that common law may no longer be good law or, at least, that it is developing consistently with Charter jurisprudence. ${ }^{144}$ For these reasons, I have grouped consideration of illegally or unfairly obtained evidence together with privileged evidence and statutorily prohibited evidence.

Once again, I have emphasized the word "and" connecting the listing of privileged evidence, illegally or unfairly obtained evidence and statutorily prohibited evidence in the admissibility flowchart since if the offered evidence is inadmissible under any of these rules, it is inadmissible.

\section{Timing of the Offer}

The timing of an offer of evidence may determine its admissibility. ${ }^{145}$ Evidence offered in a party's case in chief may be inadmissible whereas the same evidence offered later in its case in chief, in cross-examination of an opponent's witness or in rebuttal may be admissible. This is because the issues properly before the trier of fact may change during the trial, thus changing the bounds of what evidence is relevant.

The classic example involves the character of an accused in a criminal proceeding. As already mentioned, ${ }^{146}$ the Crown in general may not, subject to certain exceptions, lead evidence of the bad character of the accused. ${ }^{147}$ However, if the accused elicits evidence of his or her good character, character is put in issue and the Crown may then rebut with evidence of bad character. ${ }^{148}$ The Crown may do this by calling witnesses at its next opportunity to do so or by cross-examination of defence witnesses. It is important to note that the accused may put character in issue either in cross-examination of a Crown witness or examination-in-chief of a defence witness, whether the accused or another. ${ }^{149}$ If the accused puts character in issue by cross-examining a Crown witness, Supra at text accompanying notes 67-76. Supra at text accompanying notes 74-76.

See, generally, 1 Wigmore on Evidence (Tillers rev.), section 17, at 787.

Supra at text accompanying note 126.

$R$. v. Beland and Phillips (1987), 36 C.C.C. (3d) 481 (S.C.C.) at 491.

$R$. v. McFadden, supra, note 5 at $12-13 ; R$. v. Beland and Phillips supra.

$R$. v. McFadden, supra, note 5 at 13 .
} 
the Crown may, while still presenting its case in chief, lead evidence of the accused's bad character. On the other hand, if the accused puts character in issue during his or her case in chief, the Crown may cross-examine defence witnesses to obtain admissions of the accused's bad character but must wait for rebuttal to lead its own witnesses in that regard. ${ }^{150}$ More generally, if a party raises an issue which was not initially in dispute, the opponent will be permitted to lead rebuttal evidence. ${ }^{151}$

\section{Party Offering}

The admissibility of offered evidence may depend upon which party is making the offer.

First, evidence elicited by a party from its own witness in examination-in-chief may be inadmissible whereas the opponent may properly elicit the same evidence in crossexamination. For example, evidence of a witness' previous consistent statement may not in general be elicited during direct examination since such evidence is self-serving. ${ }^{152}$ In some circumstances, however, such evidence is admissible. For example, it may be admissible to show the party's state of mind at a particular time, to rebut a suggestion of recent fabrication or if the statement is admissible as res gestae. ${ }^{153}$ In cross-examination such evidence could be elicited, although for tactical reasons the situations in which this would be done, other than to recommit a witness as part of the foundation for impeachment, are likely few. If, however, the witness was challenged in crossexamination with a suggestion of recent fabrication, the previous consistent statement of the witness could then be elicited in reexamination. ${ }^{154}$

Second, evidence of a given content may be admissible if offered by one party but not the other, independent of the stage of witness examination. An out of court statement by an accused to a person in authority offered in evidence by the Crown is admissible if the statement was made voluntarily. ${ }^{155}$ However, the same statement offered in evidence by the accused will in general be inadmissible since it is self-serving. ${ }^{156}$ Another example is what may be called the statement by an unavailable person against penal interest exception to the hearsay rule, which is available to an accused offering exculpatory evidence but not to the Crown offering evidence inculpatory of the accused. $^{157}$

A different manifestation of the significance of which party is the proponent occurs in a case where the same stated rule applies to both parties but the rule is applied less rigidly

\footnotetext{
150. $\quad$ R. v. McFadden, supra, note 5.

15ı. R. v. Perka (1982), 69 C.C.C. (2d) 405 (B.C.C.A.) at $412-414$, affirmed (1984), 14 C.C.C. 93 d) 385 (S.C.C.).

152. R. v. Beland and Phillips (1987), 43 D.L.R. (4th) 641 (S.C.C.).

153. R. v. Graham, [1974] S.C.R. 206; R. v. Risby (1976), 32 C.C.C. (2d) 242 (B.C.C.A.), affirmed (1978), 39 C.C.C. (2d) 567 (S.C.C.); Simpson v. The Queen, [1988] 1 S.C.R. 3 at 22.

154. Welstead v. Brown, [1952] 1 S.C.R. 3 at 20-21. See also, Schiff, S., supra, note 91 at 601-602.

155. Supra at text accompanying note 116.

156. R. v. Beland and Phillips, supra, note 152.

157. Lucier v. The Queen, supra, note 44.
} 
in the case of evidence offered by one of them. An example is an offer of similar fact evidence. Whether the evidence is offered by the accused or the Crown, the proponent must establish that the probative value of the evidence exceeds its prejudicial effect. However, "the idea of a sliding scale of admissibility" is introduced and "the possibility is left open that ... where there is less prejudice to overcome ... the degree of probative value required for admission may be lower". ${ }^{158}$

\section{Formal and Procedural Requirements Affecting Admissibility}

Counsel must distinguish between leading and non-leading questions and know when each technique is permissible. ${ }^{159}$ If the question is ruled improper, the evidence elicited is never led before the trier of fact. Thus, while there is no ruling on the evidence's admissibility per se, the net result to the proponent of a ruling that a question is improper is the same as one that the offered evidence is inadmissible. Similarly, documentary evidence may be required to meet formal requirements. For example, a document may have to be certified by a designated person as accurate to be admissible.

As a prerequisite to evidence being admissible at trial, notice to the opponent may be required. This is an increasingly common requirement with respect to expert opinion evidence and, in particular, reports of experts. ${ }^{160}$ Similarly, failure to comply with other procedural requirements may render evidence inadmissible. For example, failure to produce a document on discovery may render it inadmissible at trial. ${ }^{161}$

\section{Cross-examination of Witness Versus Extrinsic Evidence}

Even if cross-examination of a witness on a particular matter is proper, a party will not be permitted to lead extrinsic evidence to contradict the witness if the matter is a collateral one. ${ }^{162}$ This is the domain of the problematic collateral facts rule which, happily, we need not explore further for present purposes. The point here is that the scope for permissible impeachment by extrinsic evidence is narrower than the scope for permissible cross-examination. Thus in some cases admissibility depends upon whether the evidence is elicited in cross-examination or offered as extrinsic evidence.

The cross-examination versus extrinsic evidence distinction overlaps with some of the other factors already considered but is different from them. It is similar to the timing factor in that cross-examination of a witness occurs during the opponent's case whereas leading extrinsic evidence occurs when the proponent has carriage of the trial. However, it is different since there need be no change in the facts in issue to make the crossexamination versus extrinsic evidence factor applicable. Likewise, this factor is similar to the form of offer factor in that cross-examination of the witness is an offer of testimony whereas the impeaching extrinsic evidence may be testimony, a document or any other

\footnotetext{
158. $\quad R$. v. $B(C . R)$, supra, note 27 at 10.

159. Maves v. Grand Trunk Pacific R. Co. (1913), 14 D.L.R. 70 (Alta. S.C.).

360. For example, The (British Columbia) Evidence Act, R.S.B.C. 1979, c. 116, ss. 10, 11.

161. For example, (British Columbia) Rules of Court, Rule 26(14).

162. The Attorney-General v. Hirchcock and Krause v. The Queen, supra, note 48.
} 
form of evidence. However, it is different in that the form of offer may be the same, since cross-examination is testimony and the offer of extrinsic evidence may be testimony as well.

\section{Nature of the Proceeding}

I submit below that the same structuring of admissibility rules may usefully be applied in both civil and criminal proceedings. ${ }^{163}$ However, the nature of the proceeding is important in at least two ways. First, since legislative jurisdiction to enact admissibility rules is divided between the federal and provincial legislatures, different statutory provisions apply to different proceedings. ${ }^{164}$ Second, admissibility rules may be less stringently applied in a criminal proceeding in the case of exculpatory evidence offered by an accused. ${ }^{165}$

\section{QUESTION 2: IS THE EVIDENCE ADMISSIBLE FOR SOME LIMITED PURPOSE?}

\section{A. INTRODUCTION}

The problems raised by multiple relevance have already been introduced. ${ }^{160}$ Also, the trial purpose for which evidence is offered has been considered as one of the factors determining admissibility ${ }^{167}$ If evidence is admissible, is it admissible at large or only for some limited purpose? That is, may the trier of fact consider all of the relevancies of the evidence or only one or some? If the latter, is a cautionary instruction as to the limited permissible use of the evidence required?

An important question is whether it is realistic to make admissibility decisions based on the assumption that the trier of fact - whether the judge or a jury - is capable of following an instruction on the limited purpose for which evidence was admitted. One bold judge expressed the opinion that such a limiting instruction may be "an offence against common sense" which "lacks the ring of reality [and] is transparently ... adopted for comfort". ${ }^{168}$ However, judges generally do not appear to share such concerns and adhere to the traditional wisdom that the trier of fact is able to and does follow even difficult instructions on the limited use to which evidence may be put. ${ }^{169}$

The following are some examples of multiple relevance problems and limiting instructions.

Infra at text accompanying notes 187-190. In this article I am only dealing with admissibility of evidence at trial. In particular, I am not considering admissibility of evidence at a preliminary inquiry, on discovery in a civil proceeding or before administrative tribunals.

See Canada Evidence Act, R.S.C. 1985, c. C-5, s. 2, and, for example, The (British Columbia) Evidence Act, R.S.B.C. 1979, c. 116, s. 2.

Recall supra at text accompanying notes 43-44.

Supra at text accompanying note 9.

Supra at text accompanying note 18.

McInroy and Rouse v. The Queen, supra, note 5 at 624-625, 635, per Estey, J.

Corbett v. The Queen, supra, note 28 at 397-404. 


\section{B. SOME EXAMPLES}

\section{Hearsay Versus Original Evidence}

Admissible hearsay (that is, evidence admissible as an exception to the hearsay rule) may be considered as evidence of the truth of the contents of the declaration whereas evidence admissible as original evidence is not evidence of the truth of the contents of the declaration but only that the declaration was made. ${ }^{170}$ The difficulty in practice with this distinction is that while evidence directly asserting a fact may be excluded, evidence from which that fact may readily be inferred may be admissible. ${ }^{171}$ This paradox has stimulated a move away from the traditional assertion-based definition of hearsay to the so-called declarant-based theory. ${ }^{172}$

\section{Previous Conviction}

Evidence admissible under statutory provisions permitting a witness to be crossexamined concerning a previous conviction goes to credibility only, not substantive issues in trial. ${ }^{173}$

\section{Previous Statement}

Evidence of a witness' previous statement, not adopted by the witness, is admissible only with respect to credibility, not the substantive issues in trial. ${ }^{174}$

\section{Character Versus Credibility of the Accused}

The basic rules dealing with the character and credibility of the accused have already been mentioned. ${ }^{175}$ Evidence of the good character of the accused may be the basis for an inference that the accused was not likely to have committed the crime charged and the trier of fact should be so instructed. ${ }^{176}$ However, evidence of the bad character of the accused admitted in rebuttal is not admissible to support an inference that the accused is the type of person who is likely to have committed the crime alleged but only to rebut the effect of the evidence of good character. ${ }^{177}$ Additionally, however, such evidence may have probative value in its own right on the issue of guilt and, if the accused has testified, may have a bearing on the credibility of the accused. ${ }^{178}$

17. See, Blastland v. Director of Public Prosecutions, [1986] A.C. 41 (H.L.); Tribe, L.H.: Triangulating Hearsay, 87 Harv. L. Rev. 957 (1973-74); Robertson, B.: Comment: Abolishing the hearsay rule?, [1989] New Zealand L.J. 231. McInroy and Rouse v. The Queen. [1979] I S.C.R. 588. 


\section{Similar Fact}

The judge should instruct the trier of fact as to the particular purpose for which the similar fact evidence is admissible and should indicate that the evidence is not admissible to establish that the accused (or party in a civil proceeding) is a person of a particular type, character or disposition who likely acted consistently with that type, character or disposition. That is, the judge should warn the trier of fact to avoid the "forbidden reasoning" of considering the character of the accused (or party). ${ }^{179}$ Of course, if the accused has put his or her character in issue, then similar fact evidence may be admissible to rebut the evidence of good character. ${ }^{180}$

\section{Statement by Co-party}

Evidence of a statement by a party to a civil proceeding is in general admissible only against him or her and not against a co-party. ${ }^{181}$ Similarly, evidence of an accused's statement, whether made to a person in authority or someone else, is not in general admissible against a co-accused. A notable exception is evidence of a statement by a coconspirator in furtherance of the conspiracy, which is admissible against all co-conspirators both in civil and criminal proceedings. ${ }^{182}$ Similarly, evidence of a party's statement is admissible against all co-parties if admitted as part of the res gestae. ${ }^{183}$

\section{NOTE ON WEIGHT GIVEN TO EVIDENCE}

Subject to a cautionary instruction as to the limited purpose for which evidence is admissible, the weight to be given to evidence is exclusively a matter for the trier of fact. In particular, the credibility of witnesses and, therefore, the weight to be put on their evidence, is a matter for the trier of fact. ${ }^{184}$ Of course, counsel are permitted to make

Ibid. at 353-354; R. v. D.(L.E.), supra, note 129 at 128.

Guay v. The Queen, [1979] I S.C.R. 18.

Harris v. Harris, [1931] 4 D.L.R. 933 (Ont. S.C.).

$R$. v. Barrow, supra, note 54.

See $R$. v. Klippenstein (1981), 57 C.C.C. (2d) 393 (Alta. C.A.), in which evidence of a co-accused's statement was, at the request of both counsel for the accused and the co-accused, admitted as part of the res gestae. Further, counsel submitted that the evidence was admissible as an exception to the hearsay rule rather than as original evidence. Somewhat to the surprise and dismay of the accused and co-accused, the evidence of the exculpatory statements of the accused revealed inconsistencies in their versions of the events and, since the evidence was admissible against all co-accused, adverse findings of credibility were made against the co-accused and they were convicted.

R. v. McDonald (1885), 10 0.R. 553 (C.A.) at 556; White v. The King (1947), 89 C.C.C. 148 (S.C.C.) at 151; $R$. v. Augello and Tascarello, [1963] 3 C.C.C. 191 (Ont. C.A.) at 192; $R$. v. Dass (1979), 8 C.R. (3d) 224 (Man. C.A.) at 233-234; 1A Wigmore on Evidence (Tillers rev.), section 29, and 9 Wigmore on Evidence (Chadboum rev.), sections 2549-2551a. McWilliams, P.K.: Canadian Criminal Evidence (3rd looseleaf ed.), 1988: Toronto, page 39-2, section 39:10000, succinctly states: "It is trite to say that the admissibility of evidence is a question for the trial judge to determine while the weight which must be attached to the evidence, once admitted, is for the jury to assess. ... Since most evidence is viva voce the assessment is largely a matter of assessing the credibility of witnesses." 
submissions to the trier of fact concerning the weight which should be given to the evidence and the trial judge in charging the jury may express his or her view on the credibility of the witnesses, provided that the jury is clearly instructed that they are the sole judges of credibility. ${ }^{185}$ It should be noted that in a trial by judge and jury, there may in effect be two successive considerations of essentially the same factual question. ${ }^{186}$

\section{GENERAL APPLICABILITY OF THE ANALYSIS}

\section{A. INTRODUCTION}

My objective has been to devise an organizational structure for admissibility rules which would be of general application to both civil and criminal proceedings and to all forms of evidence. In my view it is unnecessary and, worse, potentially confusing to segregate rules applicable to different types of proceedings and different forms of evidence. The fundamental admissibility rules are the same regardless of the type of proceeding or the form of the evidence. To the extent that there is uniformity among admissibility rules and general applicability, one organizational framework should be devised.

\section{B. APPLICABLE TO BOTH CIVIL AND CRIMINAL PROCEEDINGS}

The same admissibility rules apply generally to both civil and criminal proceedings. ${ }^{187}$ For example, the definitions of hearsay, opinion and character are the same in both types of proceeding. Similarly, the basic rules with respect to the admissibility of such evidence are the same. The rules with respect to the principal categories of privilege are the same.

Admittedly, some rules of admissibility apply only in criminal proceedings and others only in civil proceedings, examples of the former being more common. In such situations the statement of the rule itself makes it apparent that the rule is limited in application. Examples are the voluntariness requirement with respect to a statement made by an accused ${ }^{188}$ the dying declaration exception to the hearsay rule dealing with evidence offered in certain prosecutions in which the death of the declarant is in issue ${ }^{189}$ and the exception to police informer privilege which arises if the informer's identity is necessary to establish the innocence of an accused. ${ }^{190}$ The emphasized words indicate how the statement of the rule itself clearly identifies the rule as being applicable only in a criminal proceeding.

\footnotetext{
185. R. v. Augello and Tascarello, supra, note 184.

186. For example, whether an accused's statement was made voluntarily: Lord Sumner, in Ibrahim v. The King, supra, note 60 at 610 , referred to the judge's determination of voluntariness, clearly a question of law, as being "one of fact".

187. See, for example, $R$. v. Francis (1874), L.R. 2 C.C.R. 128 at 133; $R$. v. Dixon (1891), 29 N.S.R. 462 (C.A.); 1 Wigmore on Evidence (Tillers rev.), section 4, page 31: "There is but one system of [admissibility] rules for criminal and for civil trials."

188. Supra at text accompanying note 116.

189. For example, $R$. v. Jurtyn (1958), 121 C.C.C. 403 (Ont. C.A.) at 404-405.

190. Bisaillon v. Keable (1983), 7 C.C.C. (3d) 385 (S.C.C.) at 411-412.
} 


\section{APPLICABLE TO BOTH PARTIES}

Generally, the same admissibility rules apply to both the plaintiff and defendant in a civil proceeding and to the Crown and accused in a criminal proceeding. ${ }^{191}$

There are qualifications to this generalization but, once again, such qualifications are best remembered simply as such and not as significant differences necessitating different analyses. The following are some examples. First, some admissibility rules are available only to assist an accused, not to work against him or her. ${ }^{192}$ Second, different rules may apply to the same evidence content depending upon which party offers the evidence. ${ }^{193}$ Third, based upon the accused's right to a fair hearing, including presenting a full defence, ${ }^{194}$ some courts have indicated that the rules of admissibility may be relaxed somewhat when the accused is offering exculpatory evidence. That is, there is a lesser onus on the accused in establishing admissibility than there is on the Crown. ${ }^{195}$ Alternatively expressed, the benefit of the doubt given the accused in a criminal proceeding extends to questions of admissibility.

\section{APPLICABLE TO ALL FORMS OF OFFER}

The same admissibility rules apply in general to all forms of offered evidence. For example, both testimony and documentary evidence may be hearsay. Similarly, a minimal reliability hurdle must be met by all offered evidence. For example, a witness must be competent and a document authenticated. However, competence and authentication are merely different manifestations of the same minimal reliability concern. Therefore, again, it is useful to consider the same admissibility analysis with respect to all forms of evidence. To the extent that particular rules apply in some situations, these are best remembered as such.

\section{CONCLUSION}

The acid test of any organizing structure is whether it works in practice. I believe that the structure offered here does work. If the admissibility factors listed are used, at least no questions which ought to be asked will be ignored. That the questions to be asked might be asked in a different order is irrelevant. What is important is that those questions be organized in some workable way which is consistent with decided authority. Hopefully an organizing structure will assist participants in the trial process better to understand the issues and the factors that are appropriately considered. Of course, no organizing structure provides answers as to whether offered evidence is admissible: only the substantive content of the law of admissibility provides such answers.

191. R. v. Williams, supra, note 47.

192. Supra at text accompanying note 157.

193. Supra at text accompanying notes $152-158$.

194. Criminal Code, R.S.C. 1985, c. C-42, ss. 650(3), 802(1); Charter, ss. 7, 11(d).

195. See $R$. v. Williams, supra, note 47; Glanville Williams: The Proof of Guilt (London: Stevens, 1963) at $211 ; R$. v. Miller (1959), 125 C.C.C. 8 at 18 (B.C.C.A.). 